Article

\title{
Conversion of Pinus nigra Plantations with Natural Regeneration in the Slovenian Karst: The Importance of Intermediate, Gradually Formed Canopy Gaps
}

\author{
Jurij Diaci, Tomaž Adamič, Andrej Rozman, Gal Fidej ${ }^{\circledR}$ and Dušan Roženbergar * \\ Department of Forestry and Renewable Forest Resources, Biotechnical Faculty, University of Ljubljana, \\ Večna pot 83, 1000 Ljubljana, Slovenia; jurij.diaci@bf.uni-lj.si (J.D.); tomaz.adamic@bf.uni-lj.si (T.A.); \\ andrej.rozman@bf.uni-lj.si (A.R.); gal.fidej@bf.uni-lj.si (G.F.) \\ * Correspondence: dusan.rozenbergar@bf.uni-lj.si
}

Received: 25 November 2019; Accepted: 10 December 2019; Published: 12 December 2019

\begin{abstract}
Since the mid-19th century, Pinus nigra plantations have played a key role in the restoration of degraded European landscapes. Nowadays, these plantations are aging and prone to natural disturbances, insect infestations, and diseases. For their successful gradual conversion, knowledge of optimal gap spatiotemporal dynamics is crucial. We studied herb and natural regeneration patterns along with site factors on 477 subplots within 44 plots distributed over four stand types: closed stand (14\% diffuse light), open stand (21\%), gap edge (23\%), and gap (57\%). Despite the abundant Quercus petraea, Q. cerris, and Q. pubescens mast year, no one-year seedlings were recorded, which is likely due to the summer drought. Short seedlings $(\mathrm{h}<20 \mathrm{~cm})$ of Quercus sp., Fraxinus ornus and Ostrya carpinifolia were more successful within closed stands. Short Quercus seedlings were positively associated with soil depth and negatively associated with soil nutrients, distance to seed trees, and Sesleria autumnalis coverage. Taller Quercus seedlings required more light than both of its strongest competitors and were positively related to humid soils and less rocky sites. Ungulate overbrowsing significantly impeded natural regeneration. The results indicate a satisfactory Quercus density for conversion and the importance of advanced regeneration, which should be gradually, but persistently, released by progressively widening gaps.
\end{abstract}

Keywords: gap partitioning; microsite partitioning; topsoil moisture; microrelief; ground vegetation; overbrowsing; conversion; Pinus nigra; natural regeneration

\section{Introduction}

Globally, there are many former forest lands that have been degraded due to clearing, burning, and overgrazing. Afforestation of these areas could improve soil productivity, forest climate and biodiversity, as well as mitigate climate change [1]. Good practices from the past are important for encouraging new forest restoration projects and for learning [2]. Afforestation of the Karst region above the Gulf of Trieste from the mid-19th century represents one of the first successful examples of forest restoration on almost completely barren land exposed to drought and strong winds [3]. Before human colonization, the landscape was overgrown with deciduous forests consisting mainly of oaks (Quercus petraea (Matt.) Liebl., Quercus cerris L., and Quercus pubescens Willd.; hereafter Quercus), and, to a lesser extent on more mesophilic sites, Fagus sylvatica L. [4].

Due to the degraded sites in the Karst, Pinus nigra J.F. Arnold was used for restoration. Although it is not a native species on Karst, it is a specialist on shallow rocky calcareous soils and xerophytic sites. Later, P. nigra also subspontaneously expanded. There are about 16,000 ha of $P$. nigra stands alone within the Slovenian Karst region. Nowadays, P. nigra plantations across Europe are aging, 
prone to fire, and subject to different abiotic disturbances (windthrow, ice storms, droughts), insect infestations, and more recent diseases [5-7]. Native midsuccessional species, such as Fraxinus ornus L. and Ostrya carpinifolia Scop., are increasingly entering P. nigra forest stands, where they form a distinctive layer, while the natural regeneration of $P$. nigra has halted [8]. Quercus sp. return very gradually due to the lack of seed trees, degraded forest soils and overbrowsing. Conversion of $P$. nigra plantations is necessary to ensure stable future forests and represents an important, but difficult, task for silviculture [9].

In conifer plantations that are at greater risk of decline, on more degraded forests sites and where there is a lack of seed trees, direct conversion with planting is usually chosen [7]. This is the more demanding and expensive option. Under favorable conditions, the use of gradual conversion based on natural regeneration is the better choice [10,11]. For the latter, one of the key questions involves the optimal spatiotemporal dynamics of the gaps to achieve quality mixed stands with sufficient, mostly light demanding Quercus sp., which are robust and valuable tree species vital for the multipurpose functioning of future forests.

Research from the broader European region on planted as well as natural P. nigra and Pinus sylvestris L. stands in succession indicates the importance of the proximity of Quercus seed trees, animal seed dispersal by birds, and successful Quercus recruitment in intermediate gaps [12-14]. Several studies of $P$. nigra and P. sylvestris stands in succession have stressed the importance of regular thinning for Quercus stands, and longer periods of Quercus advance regeneration survival under Pinus crowns when compared to broadleaved stands $[11,13,15]$. However, few studies have relied on detailed ground vegetation assessment for indication of site factors supplemented by direct measurements of light climate and soil moisture, both of which are likely to have an important impact on Quercus regeneration, especially in the sub-Mediterranean region. The research objectives of this study were to analyze the seedling structure and its dependence on abiotic (e.g., light, soil moisture, relief) and biotic factors (e.g., competition from trees and herbs, presence of seed trees) and to propose guidelines for the transformation of $P$. nigra stands based on natural regeneration.

\section{Materials and Methods}

\subsection{Stand and Site Characteristics}

The study was carried out in the Karst region of southwest Slovenia, as seen in Figure 1. The analyzed $P$. nigra plantations are located on flatlands or gentle slopes above an altitude of 235-450 m a.s.l. Carbonate parent material dominates, but there are some small pockets of silicate in the form of chert, flysch, and sands. The soils are eroded and mainly in the form of shallow rendzina [16]. In some places, especially in depressions, deeper brown soils have developed. In addition to soil variability, land degradation has also occurred at different intensities; therefore, the potential natural vegetation is difficult to determine [4]. In more favorable ecological conditions, stands were most likely dominated by sessile oak (Q. petraea) (Seslerio-Quercetum sensu Braun-Blanque typology), while less favorable sites were dominated by downy oak (Q. pubescens), hop hornbeam and flowering ash stands (Ostryo-Quercetum pubescentis). Pinus nigra stands in Slovene Karst experience severe droughts in summer and higher precipitation than most natural P. nigra stands in Europe, which makes them prone to fungal diseases. Therefore, even greater management risks are expected in the future. At present, most stands are two-storied, with $87 \%$ P. nigra in the overstory and about $10 \%$ F. ornus and O. carpinifolia in the understory. Quercus and the noble broadleaves amount to only $3 \%$ in the total growing stock. Average growing stock varied from $148-223 \mathrm{~m}^{3} \mathrm{ha}^{-1}$ and increment 3.3-5.1 $\mathrm{m}^{3} \mathrm{ha}^{-1}$ year $^{-1}$. Stands were between 80 and 120 years old, and the upper stand height was about $25 \mathrm{~m}$. The mean annual temperature in the period $2000-2011$ was $12.0^{\circ} \mathrm{C}$, and the mean sum of yearly precipitation was $1234 \mathrm{~mm}$, with extensive droughts in summer (Godnje meteorological station, $760 \mathrm{~m}$ a.s.1.; [17]). The climate is sub-Mediterranean. 


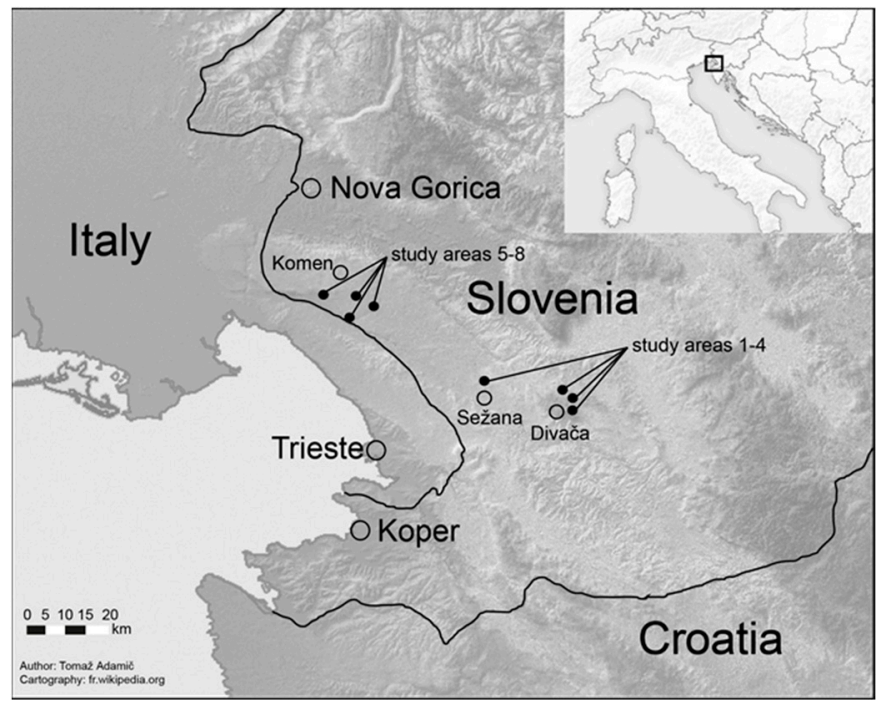

Figure 1. Location of eight study areas where 44 research plots were installed.

\subsection{Sampling Design and Recordings}

The study object was the entire area of P. nigra plantations on comparable sites with mature stands and stands in regeneration, in which there had been no logging in the five years prior to the study. We randomly selected eight locations from the study object and installed 44 plots $25 \times 25 \mathrm{~m}$ in size, as seen in Figure 2. The plots were randomly selected within four stand types: closed stand, partially open stand, the edge of a canopy gap and the center of a canopy gap. The gaps ranged from 1.2 to 4.4 ha in size. Until recently, mature stands were mostly lightly thinned, and managers only rarely formed gaps deliberately. Thus, it was not possible to select a balanced set of treatments in each location. For each plot, we sampled the main ecological features (relief type, rockiness, slope inclination, and orientation) and typical dendrometric data (e.g., tree species coverage, full inventory of dbh and heights).

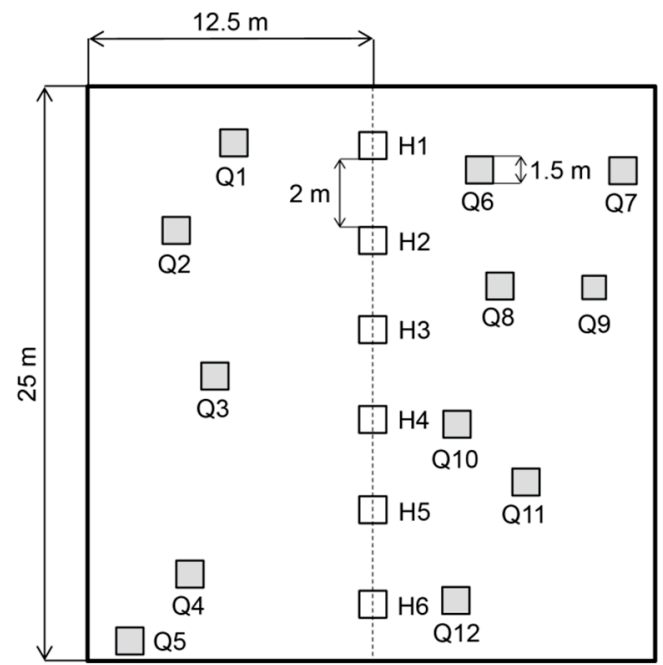

$\underset{\oint}{N}$

Figure 2. Sketch of plot with arrangement of herb subplots (H1-H6) in white and Quercus subplots (Q1-Q12) in grey.

Across the center of each plot, six systematic herb subplots were placed, and two rows of Quercus subplots were arranged to the left and right of the central transect, as seen in Figure 2. The first two herb subplots were located $1 \mathrm{~m}$ south and north of the plot center. The minimum distance between the two herb or Quercus subplots was $2 \mathrm{~m}$. The center of the Quercus subplots was defined by the presence of Quercus seedlings older than one year. The size of the subplots was $1.5 \times 1.5 \mathrm{~m}$. The herb subplots 
were installed and recorded on all plots $(N=264)$, while the number of Quercus subplots varied from 0 to a maximum of $12(N=214)$. On each subplot ground vegetation coverage according to species was estimated visually from above and recorded to the nearest $10 \%$ from $10 \%$ to $100 \%$ and to the nearest $1 \%$ from $1 \%$ to $10 \%$. Thus, the cumulative cover of herbs and shrubs often exceeded $100 \%$. The same scale was also used for the estimation of coarse woody debris (CWD) and rock coverage (rockiness) on the forest floor. Microrelief (flat, concave, convex), slope inclination and orientation, soil depth, and cumulative depth of the organic horizons (L-litter, F-fermentation horizon and H-humus horizon; hereafter referred to as LFH) were measured. Regeneration density according to species was estimated corresponding to four height classes (one-year old seedlings, seedlings with height $<20 \mathrm{~cm}$, seedlings with height $\geq 20$ and $<130 \mathrm{~cm}$ and seedlings taller than $130 \mathrm{~cm}$ ). Seedlings were categorized as browsed if the leading shoot was damaged.

On a sample of plots $(n=232)$, relative diffuse light $1.3 \mathrm{~m}$ above each subplot was assessed with two point quantum sensors (LI-COR, Inc., Lincoln, NE, USA), one placed above the subplot and the second in a nearby open area. Measurements were taken on overcast days [18]. On the same sample of subplots, topsoil water content $(0-10 \mathrm{~cm})$ was measured using time domain reflectometry [19] in September 2012 (moisture1) and October 2012 (moisture2). Each time measurement was taken after a period of dry weather. In 2012, only $400 \mathrm{~mm}$ of rainfall fell in the period from May to September, which is $73 \%$ of the average in the 2001-2011 vegetation period. At the same time, the average July air temperature at the Bilje meteorological station was $1.6{ }^{\circ} \mathrm{C}$ above the long-term average (2001-2011). Measurements of topsoil moisture in 2012 thus indicated topsoil moisture following hot and dry summers [20]. We also sampled features of Quercus seed trees and their distance to subplots in a radius of $80 \mathrm{~m}$ from each plot.

\subsection{Data Analysis}

Data were analyzed in R Version 3.6.1 [21]. Seedling density in relation to ecological factors was modeled with a series of generalized mixed-effects models (GLMMs) with negative binomial distribution and a logarithmic link function [22] since the data were overdispersed. All final models were selected following a top-down approach [23]. Different models with all combinations of ecologically meaningful fixed effects (comp. Section 3.4), were built. These models were then compared against simpler nested models based on the ANOVA likelihood ratio test of fits for GLMMs [22]. Research units (i.e., plots) were considered as random factors. For model diagnostics, we inspected confidence intervals of parameters and examined sets of graphical summaries [24]. Light and topsoil moisture measurements were carried out on a sample of subplots $(n=215)$; thus, separate GLMMs for this subsample were carried out.

Mean Landolt indicator values (LIVs for temperature regime, continentality, light quantity, topsoil moisture, soil reaction, nutrient content in the soil, humus content, and soil aeration) were estimated as a weighted average of the Landolt indicator values [25] of all present understory layer species, and their abundances were used as weights [26]. Principal coordinate analysis (PCoA) was used to ordinate subplots based on the 2012 vegetation survey. The distance matrix was calculated by applying the Bray-Curtis distance measure to the square root of the plant species coverage data. Based on inspection of the eigenvalues, we selected only the first and second principal coordinate for presentation. Ecological variables (light and topsoil moisture measurements, distance to beech seed trees, etc.), mean LIVs, and seedling density according to species groups were fitted onto an ordination plot using the vegan package [27]. In identifying the indicator species of each group, we used the Indicator Value Index and its components [28] using the package indicspecies [29]. Differences in ecological factors between stand types and subplot types were tested with the nonparametric Kruskal-Wallis and Wilcoxon tests. 


\section{Results}

\subsection{Variability of Ecological Factors within and between Stand Types}

The median of relative diffuse light amounted to $13.8 \%$ below the closed stand and increased through the open stand (20.8\%) and gap edge (23.1\%) to the gap, at $57.3 \%$, as seen in Figure 3 . The lowest variability of light conditions was measured below the closed stand, followed by the gap edge, the open stand and lastly the gap, which exhibited considerably higher variability. The light distribution was followed by the response of the cumulative coverage of herbs and shrubs with the lowest values below the closed stand (55.0\%), followed by the open stand (91.3\%), the gap edge $(100.0 \%)$, and the gap (100.1\%). The overall topsoil humidity was lower in September compared to October 2012, with medians of $10.0 \%$ and $22.4 \%$, respectively. In September, topsoil moisture was higher under the closed stand when compared to the other three stand types, while in October, the differences were smaller, as seen in Figure 3. The LIV for light followed a similar gradient to that of measured diffuse light, with increasing levels from the closed stand to the gap ( $\mathrm{K}-\mathrm{W} p<0.001)$. LIV for continentality $(\mathrm{K}-\mathrm{W} p<0.001)$ and nutrients $(\mathrm{K}-\mathrm{W} p=0.0013)$ also indicated increasing values towards the gap. Phytoindication LIV values for soil moisture indicated lower values in the open stand and at the gap edge $(\mathrm{K}-\mathrm{W} p=0.0013)$.
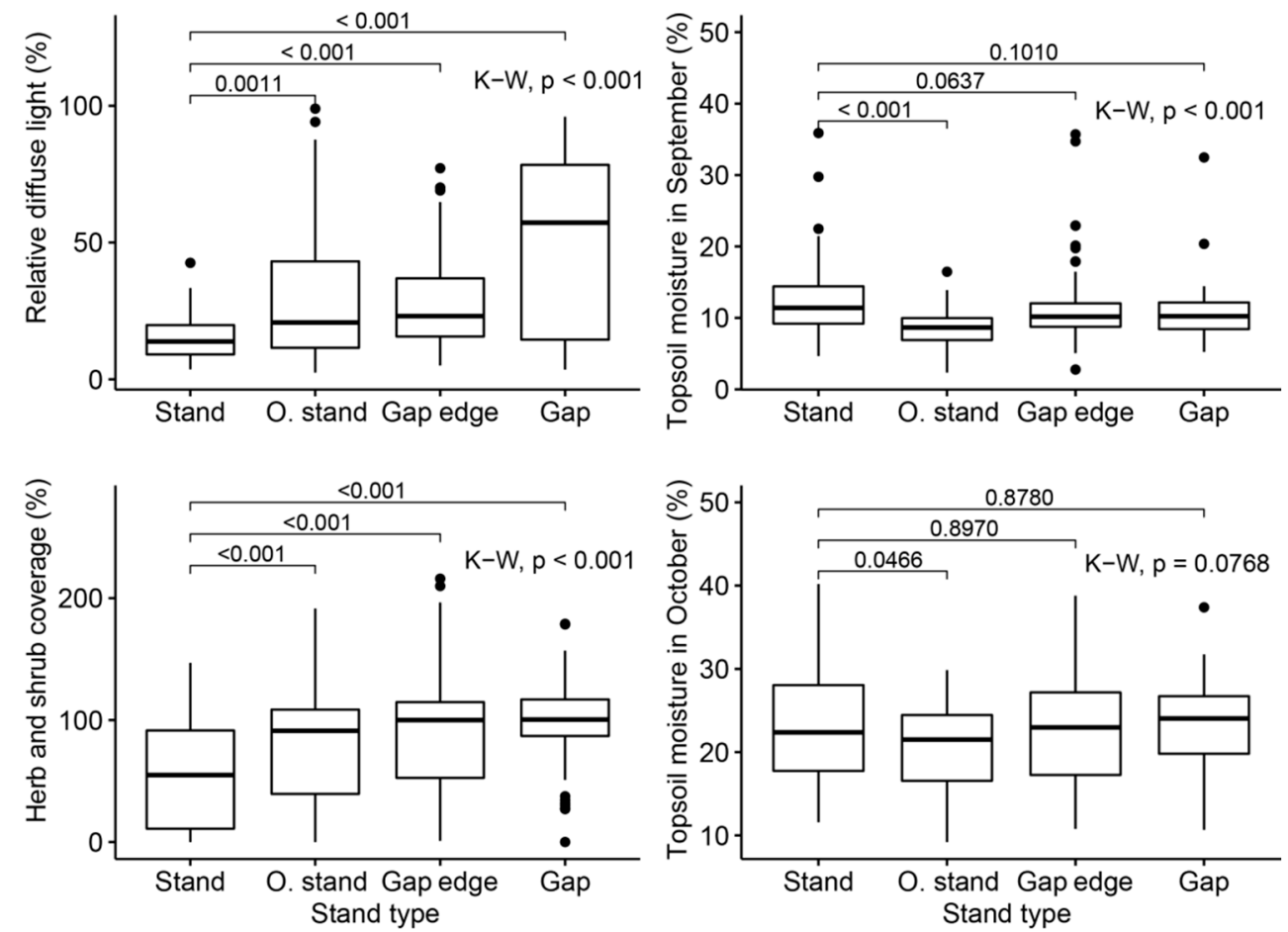

Figure 3. Box and whisker plots of relative diffuse light, topsoil moisture in 2012 and herb and shrub coverage according to stand type. The numbers above the whiskers denote significance levels between stand types. K-W stands for the Kruskal-Wallis test.

\subsection{Natural Regeneration}

The regeneration density on both herb and Quercus subplots was high, at nearly 30,000 trees ha ${ }^{-1}$ on average, as seen in Table 1. Although 2011 was an abundant Quercus mast year, we did not record any one-year-old seedlings. In a separate sample outside our plots, we dug out 38 Quercus seedlings and found that only $5 \%$ were of a vegetative origin. Herb plots give an unbiased assessment of overall regeneration structure, and they indicated domination of F. ornus at 73\%, followed by Quercus at $10 \%$, O. carpinifolia at $9 \%$, and Ulmus glabra Huds. aggr. at $2 \%$. The noble broadleaves (Acer pseudoplatanus L., Acer obtusatum Waldst. \& Kit ex Willd., Prunus avium L., Tillia cordata Mill., T. platyphyllos Scop., 
Fraxinus excelsior L., and Sorbus torminalis (L.) Crantz) and other species amounted to 6\%, as seen in Appendix A. From the composition of regeneration according to height class, we can observe a slight decrease in the share of F. ornus, a considerable decrease in Quercus and noble broadleaves, and an increasing share of $O$. carpinifolia, as seen in Figure $4 \mathrm{a}$. It seems that the average growth conditions do not allow recruitment of the first group of tree species to higher regeneration classes. This is even more evident if we look at the regeneration structure according to tree species, height class, and stand type (Section 3.4).

Table 1. Density of regeneration per hectare according to subplot type, height class, and tree species. Legend: N. Brd.-Noble Broadleaves.

\begin{tabular}{cccccccc}
\hline \multicolumn{7}{c}{ Herb Subplots } \\
\hline Height Class & F. ornus & O. carpinif. & Quercus & Ulmus & N. Brd. & Other & Sum \\
$\mathrm{h}<20 \mathrm{~cm}$ & 9616 & 321 & 1859 & 270 & 710 & 152 & 12,928 \\
$20 \leq \mathrm{h}<130 \mathrm{~cm}$ & 9632 & 1724 & 794 & 253 & 744 & 51 & 13,164 \\
$\mathrm{~h} \geq 130 \mathrm{~cm}$ & 1335 & 422 & 68 & 17 & 51 & 68 & 1960 \\
Total & 20,583 & 2467 & 2721 & 541 & 1504 & 270 & 28,086 \\
\hline \multicolumn{7}{c}{ Quercus Subplots } \\
\hline $\mathrm{h}<20 \mathrm{~cm}$ & 8494 & 353 & 4237 & 166 & 228 & 42 & 13,520 \\
$20 \leq \mathrm{h}<130 \mathrm{~cm}$ & 6397 & 1059 & 6044 & 332 & 187 & 145 & 14,164 \\
$\mathrm{~h} \geq 130 \mathrm{~cm}$ & 748 & 602 & 166 & 0 & 0 & 21 & 1537 \\
Total & 15,639 & 2015 & 10,447 & 498 & 415 & 208 & 29,221 \\
\hline
\end{tabular}
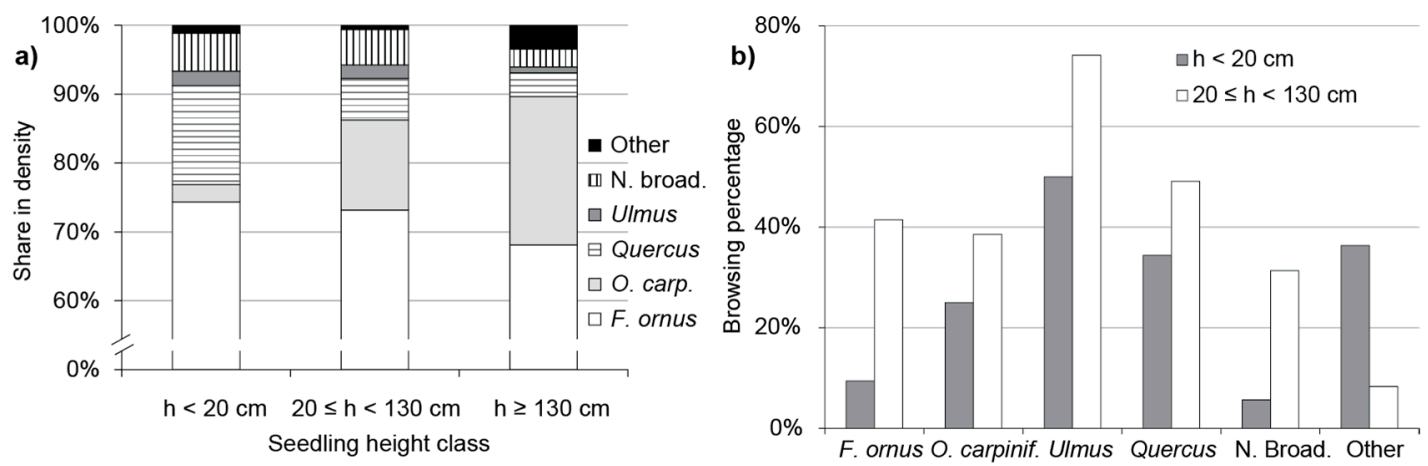

Figure 4. (a) Seedling species composition according to height class in the herb subplots. (b) Percentage of seedlings with terminal shoot browsed according to tree species and height class.

Within the first $(\mathrm{h}<20 \mathrm{~cm})$, second $(20 \leq \mathrm{h}<130 \mathrm{~cm})$ and third regeneration height class $(\mathrm{h} \geq 130 \mathrm{~cm})$, the average share of seedlings damaged by ungulates amounted to $16 \%, 43 \%$, and $26 \%$, respectively. The overall browsing damage rate was 30\%. Virtually all tree species were most damaged in the second height class, as seen in Figure 4b. Among the species, Ulmus was the most damaged, followed by Quercus, F. ornus and O. carpinifolia.

\subsection{Herb Vegetation and Indication of Ecological Factors}

We recorded 28 species of trees, 31 species of shrubs, and more than 120 species of herbs, which is by far more than that recorded in similar research in other phytogeographic regions of Slovenia. Ordination of vegetation indicated two main gradients, as seen in Figure 5. The first seems to be influenced by stand type. LFH thickness, CWD, and rockiness increase in the direction of closed stand conditions, while LIV for soil moisture and minimum and average distance to seed trees decrease. However, the centroids of stand types are located close together, indicating that other factors are also important, e.g., geographical distances between the plots. The second gradient, which is independent of the first, indicates changes in LIV for reaction, continentality and light as well as slope and coverage 
of Sesleria autumnalis Scop. The density of shorter and taller F. ornus and O. carpinifolia seedlings increases in the direction of closed stand. The seedling density of shorter Quercus seedlings was not significantly related to the ordination axes, while taller seedlings seem to be more associated with LIV for light than O. carpinifolia or F. ornus. The density of species that were significantly related to the ordinal axes was not related to $S$. autumnalis coverage.

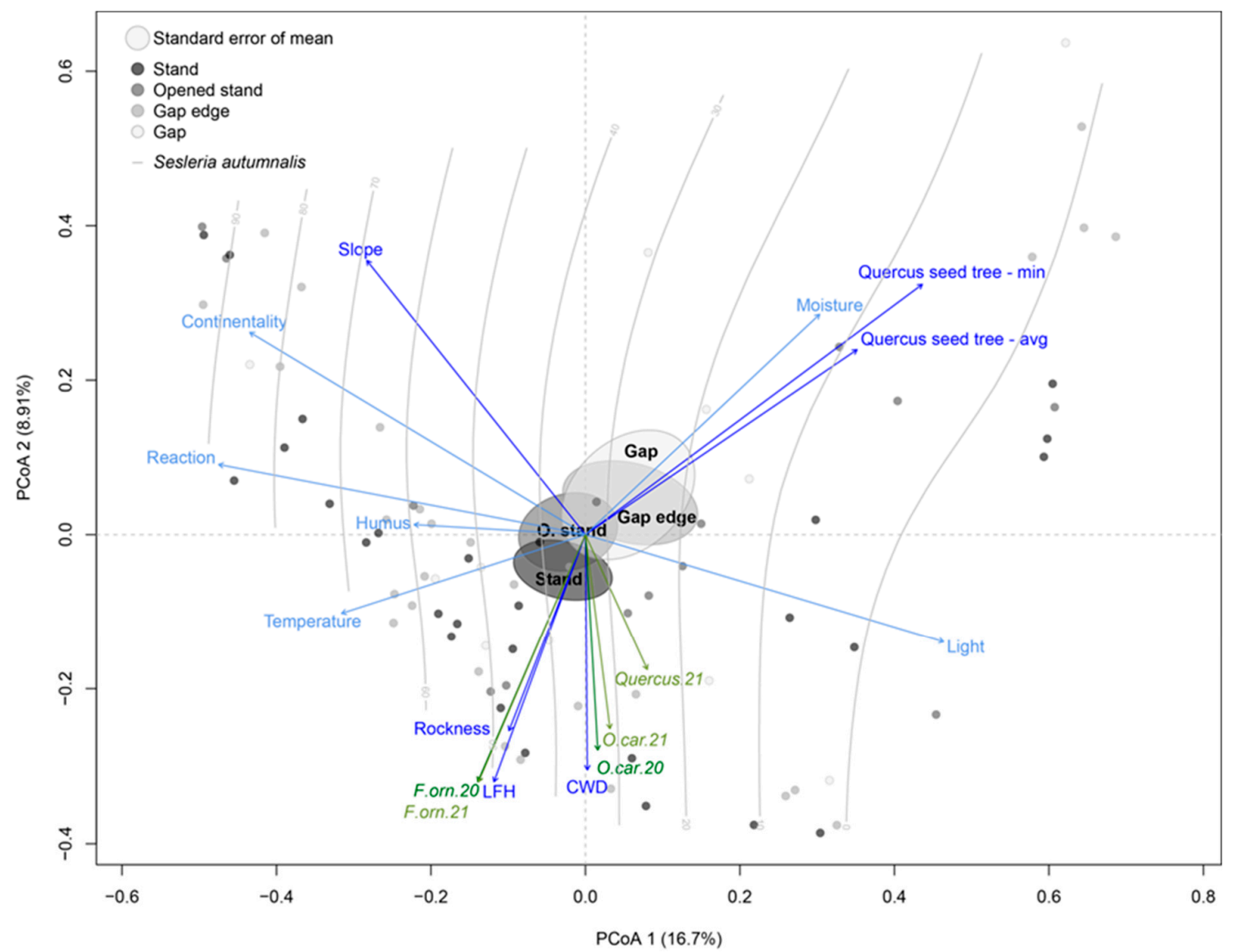

Figure 5. Ordination biplot of a principal coordinate analysis (PCoA) for vascular plant cover in the herb layer (Bray-Curtis distance measure) in 2012. Grey circles represent the location of plots on the first and second axes of the PCoA analysis. The arrows show the direction of the gradient, and the length of the arrows is proportional to the correlation between the variable and the ordination. Only factors with a $p$-value $<0.05$ are plotted, with the exception of rockiness $(p=0.1)$. Smaller angles between the arrow and axis represent a higher correlation between the two values. Green arrows represent regeneration density per species and developmental stage, e.g., F.orn.20 for F. ornus short seedlings. Dark blue arrows represent measured ecological factors, e.g., CWD coverage, LFH thickness, and minimum and average distance to Quercus seed trees. Light blue arrows are for Landolt phytoindication values for light, continentality, temperature, reaction, nutrients, and soil moisture.

\subsection{Drivers of Regeneration Dynamics}

From the differences in ecological factors between the herb and Quercus subplots, we can deduce the peculiarities of the microsites where Quercus regenerated. Significant differences were found for topsoil moisture in September $(p=0.0429)$, Rubus $s p$. coverage $(p=0.0019)$, rockiness $(p=0.0099)$, and LIV for soil reaction $(p=0.0339)$. The Quercus subplots had slightly moister topsoil, were more overgrown by Rubus sp., were less rocky and had lower soil reaction. Herb species with the highest specificity (association) with herb subplots were Corylus avellana L., Salvia pratensis L., and Euphorbia 
nicaeensis All., while Rubus ulmifolius Schott, Rosa arvensis Huds. and Lamium galeobdolon L. were associated with Quercus subplots.

Models for the density of shorter Quercus and F. ornus seedlings predicted a significant decrease from the closed stand, through the open stand and gap edge, to the gap, as seen in Figure 6 and Table 2. The lowest density of all three main tree species was recorded within the gap. Quercus seedlings taller than $20 \mathrm{~cm}$ were most frequent in the open stand, followed by the gap edge. They required more light compared to shorter Quercus seedlings. Quercus competitors, F. Ornus and O. carpinifolia, indicated similar patterns for taller seedlings. The density decline towards the gap edge and gap center was more pronounced for both competitors, but especially for O. carpinifolia, suggesting a slightly higher shade tolerance in both species. These patters were consistent on the herb and Quercus subplots.
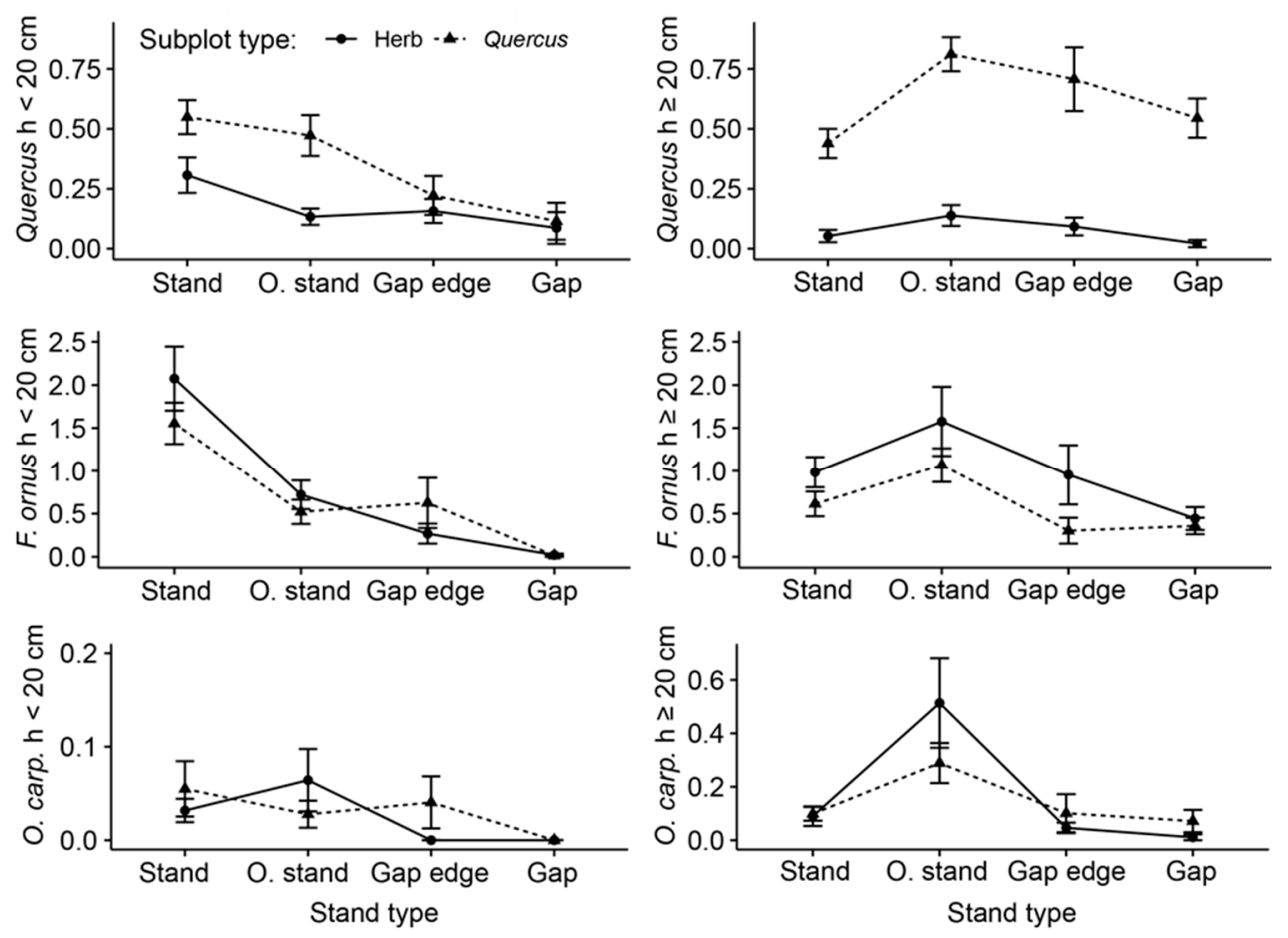

Figure 6. Mean seedling density per $\mathrm{m}^{2}$ (error bars represent the standard error) according to the main tree species, height class, stand type, and subplot type.

The density of shorter Quercus seedlings was additionally positively associated with soil depth and LIV for continentality and negatively associated with LIV for nutrients, coverage of S. autumnalis and distance to Quercus seed trees, as seen in Table 2. The GLMM model for the subsample with measured diffuse light and topsoil moisture indicated largely the same pattern with a negative association of Quercus density with distance to seed trees and diffuse light intensity, with the exception of a positive association with coverage of F. ornus. The GLMM model for taller Quercus seedlings indicated a positive association with LIV for light, LIV for soil moisture, and distance to Quercus seed trees, and a negative association with rockiness. The model for the subsample indicated a negative association with rockiness and coverage of $F$. ornus.

The density of shorter F. ornus seedlings was positively associated with soil reaction and negatively associated with LIV for nutrients, continentality and light. The density of taller F. ornus seedlings indicated a positive association with LIV for soil reaction, coverage of S. autumnalis and LFH and a negative association with LIV for continentality, soil moisture, and flat relief. The O. carpinifolia short seedling sample was too small to be modelled. The model for taller O. carpinifolia seedlings indicated a negative association between density and LIVs for continentality, light and soil moisture, as well as for rockiness. 
Table 2. Results of the generalized mixed-effects model (GLMMs) analysis of natural regeneration density according to tree species predicted by factors ( $n=477)$. Research plots were treated as random effects. Labels following factor names denote the factor levels for comparison, while the numbers in brackets within the results denote the standard error (SE).

\begin{tabular}{|c|c|c|c|c|c|}
\hline Variable & Quercus $<20 \mathrm{~cm}$ & Quercus $\geq 20 \mathrm{~cm}$ & F. ornus $<20 \mathrm{~cm}$ & F. ornus $\geq 20 \mathrm{~cm}$ & O. carpinif. $\geq 20 \mathrm{~cm}$ \\
\hline Intercept & $-0.78(1.55)$ & $-5.65(0.90)^{* * *}$ & $12.16(2.64)^{* * *}$ & $9.72(2.25)^{* * *}$ & $15.33(3.60)^{* * *}$ \\
\hline Stand type: closed vs. open & $-0.26(0.20)$ & $0.94(0.16)^{* * *}$ & $-0.72(0.21)^{* * *}$ & $0.44(0.19) *$ & $-0.61(0.40)$ \\
\hline Stand type: closed vs. gap edge & $-0.62(0.28)^{*}$ & $0.57(0.22)^{* *}$ & $-1.30(0.30)^{* * *}$ & $-0.06(0.27)$ & $-0.89(0.39) *$ \\
\hline Stand type: closed vs. gap centre & $-0.17(0.35)^{* * *}$ & $0.13(0.22)$ & $-3.61(0.67)^{* * *}$ & $-0.004(0.28)$ & $-1.28(0.36)^{* * *}$ \\
\hline Transect: Quercus vs. Herb & $0.92(0.17)^{* * *}$ & $1.95(0.16)^{* * *}$ & ns & $-0.40(0.17)$ * & ns \\
\hline Soil depth & $0.34(0.12) * *$ & ns & ns & ns & ns \\
\hline LIV nutrients & $-0.83(0.37)$ * & ns & $-2.32(0.48) * * *$ & ns & ns \\
\hline LIV continentality & $0.77(0.35) *$ & ns & $-2.21(0.42)^{* * *}$ & $-2.79(0.39) * * *$ & $-2.23(0.57)^{* * *}$ \\
\hline LIV light & ns & $0.48(0.18)^{* *}$ & $-0.92(0.33)^{* *}$ & ns & $-1.74(0.49)^{* * *}$ \\
\hline LIV moisture & ns & $0.74(0.27)^{* *}$ & ns & $-2.09(0.43)^{* * *}$ & $-1.70(0.69) *$ \\
\hline LIV soil reaction & ns & ns & $1.39(0.41)^{* * *}$ & $1.30(0.38)^{* * *}$ & ns \\
\hline Coverage S. autumnalis & $-0.29(0.11) * *$ & ns & ns & $0.42(0.09)^{* * *}$ & ns \\
\hline Distance to Quercus seed trees & $-0.12(0.05) *$ & $0.08(0.04) *$ & $\mathrm{nt}$ & nt & nt \\
\hline Rockiness & ns & $-0.48(0.22)$ * & ns & ns & $-1.73(0.44)^{* * *}$ \\
\hline LFH & ns & ns & ns & $0.09(0.03)^{* *}$ & ns \\
\hline Relief: flat vs other & ns & ns & ns & $-0.39(0.20)$ * & ns \\
\hline Random effects: a Plot & $<0.01(<0.01)$ & $<0.01(<0.01)$ & $<0.01(<0.01)$ & $<0.01(0.09)$ & $<0.01(<0.01)$ \\
\hline
\end{tabular}

a: For random effects, variance and standard deviation in parenthesis are given; Levels of significance: ${ }^{*} p<0.05,{ }^{* *} p<0.01,{ }^{* * *} p<0.001$. ns: not significant; nt: not tested. 


\section{Discussion}

In the black pine plantations of the Slovenian Karst, a significant density of Quercus (2700 ha ${ }^{-1}$ ) and noble broadleaves $\left(1500 \mathrm{ha}^{-1}\right)$ was found, mostly in form of advance regeneration. Similar Quercus seedling densities in Pinus plantations have been reported in some studies [12,13]. Higher densities have been reported in studies from Balkan mountains [11] and from Poland [14], while in some other studies the densities were lower, likely due to more extreme sites and higher stand densities [15].

Since 2011 was an abundant mast year for Quercus [30], we expected many one-year-old Quercus seedlings. However, we did not record any one-year-old seedlings from any of the main tree species in 2012, which is probably due to the dry spring and summer of that year. The period from May to September in the research area had less precipitation than the 1971-2000 average [20]. This finding is consistent with the results of other authors who conclude that tree regeneration in Mediterranean forests is restrained by drought and therefore canopy provides a significant nurse effect for seedlings [31,32].

Quercus establishment was better within closed stands, on deeper silicate soils, with less $S$. autumnalis coverage and in proximity of seed trees. The importance of soil depth, ground vegetation competition and seed trees for Quercus establishment has been emphasized in several studies [11,13,33]. In addition to stronger seed rain under forest stands and less competition from ground vegetation, small rodents and birds, especially jays (Garrulus glandarius L.), are also important factors as vectors for acorns. It appears that they prefer forest stands rather than gaps $[13,15]$.

Taller Quercus seedlings were more abundant in open stands and at gap edges, on more humid soils and on less rocky sites. Due to the deep root system of Quercus, competition with the grass S. autumnalis did not represent a major hindrance to already established Quercus seedlings. Many other researchers have stressed the relative abundance of Quercus advance regeneration in stands and problems with establishment in gap centers [11-15,33].

It seems that taller Quercus seedlings are more light demanding than competing F. ornus and O. carpinifolia; they may also better tolerate the influence of the continental climate within gaps (i.e., low relative air humidity, large daily and annual variation in temperature), especially Q. cerris and Q. pubescens [25]. However, due to the low Quercus density, it seems that gaps in this study were too large and were not made gradually following established Quercus advance regeneration. In the sub-Mediterranean region, special care is needed when regenerating stands, as gaps can also be problematic due to summer droughts [32]. Unlike other studies of topsoil moisture distribution within gaps [34,35], measurements in this study indicated that seedlings in gaps were more exposed to drought during summer months compared to closed stand (comp. [36]), despite the absence of interception by crowns and water consumption by tree roots.

An important difference between Quercus and its two main competitors is that it thrives better on deeper and more acidic soils. While the proportion of Quercus declined with height class, the proportion of F. ornus was more stable and O. carpinifolia increased in number. The latter is probably partly due to its higher shade tolerance and lower mortality, and partly also due to the successional development of stands and improved soil conditions. The ratio of Quercus to competing tree species is strongly in favor of the latter; therefore, tending and mixture regulation in favor of Quercus is needed [12].

In addition to soil conditions, overbrowsing by ungulates represents another factor that is not directly influenced by silviculture. Browsing of regeneration by ungulates exceeded the recommendations for sustainable natural regeneration [37], and in particular hampered the development of Quercus. The association of Quercus subplots with thorny species (Rosa sp., Rubus sp.) may also indicate an escape strategy for this species [38]. Thus, successful recruitment of seedlings would require a significant decrease in game density.

\section{Conclusions}

This study did not cover all gap sizes. The task of future research is to consider a larger range of gap sizes, which will be available with the further development of gradual conversion. The guidelines 
presented are therefore largely based on past Quercus regeneration studies [12,39-41] and observations and should be followed with some caution. Contrary to the common opinion that Quercus seedling potential is low in P. nigra plantations, this study indicated that gradual conversion by means of natural regeneration is feasible. This is especially true for less degraded sites with deeper, silicate soils. Quercus establishment is successful under closed stands (e.g., 15-20\% of diffuse light). Regular thinning of P. nigra stands is important to favor stability and facilitate recruitment of advanced regeneration. Later, with the development of Quercus, small gaps (e.g., 20-30\% of diffuse light) should be created and progressively expanded. Since Quercus seedlings can survive up to 25 years below P. nigra canopies, the interventions can be gradual. Low advance regeneration density and overbrowsing require strict protection of seedlings from harvesting and browsing damage as well as regulation of tree competitors. If tree commercial quality is a concern, following the thicket phase, the gap size should reach at least 0.5 ha due to the heliotropic growth of Quercus. It seems likely that at current game densities active gradual transformation of $P$. nigra plantations is not possible. Therefore, in order to promote stable mixed future forests, in addition to the described silvicultural methods, it is also necessary to regulate ungulate populations.

Author Contributions: Conceptualization and methodology by D.R., J.D. and A.R.; data curation by A.R. and J.D.; formal analysis by A.R. and J.D.; funding acquisition by J.D. and D.R.; investigation and resources by T.A. and G.F., writing — original draft preparation by J.D. and D.R.; writing-review and editing by G.F. and A.R.; visualization by A.R., J.D. and T.A.; supervision by J.D.; project administration by all authors.

Funding: This research was supported by the Slovenian Research Agency, Research Programme P4-0059 and by the research project V4-1124 financed by the Ministry of Agriculture, Forestry and Food.

Acknowledgments: The authors would like to thank two anonymous reviewers for their valuable comments.

Conflicts of Interest: The authors declare no conflict of interest.

\section{Appendix A}

List of sampled tree species and shrubs on vegetation subplots. Frequency represents the proportion of subplots where a species was present; regeneration means overall regeneration structure.

\begin{tabular}{|c|c|c|c|c|}
\hline Trees & Frequency $\%$ & Regeneration \% & Shrubs & Frequency $\%$ \\
\hline Fraxinus ornus & 70 & 73 & Hedera helix & 39 \\
\hline Quercus sp. & & 10 & Clematis vitalba & 35 \\
\hline Quercus pubescens & 20 & & Ligustrum vulgare & 30 \\
\hline Quercus cerris & 11 & & Rubus hirtus & 25 \\
\hline Quercus petraea & 3 & & Cornus mas & 21 \\
\hline Quercus rubra & 1 & & Prunus spinosa & 19 \\
\hline Ostrya carpinifolia & 37 & 9 & Crataegus monogyna & 15 \\
\hline Ulmus glabra aggr. & & 2 & Prunus mahaleb & 14 \\
\hline Ulmus glabra & 2 & & Frangula rupestris & 11 \\
\hline \multirow[t]{2}{*}{ Ulmus minor } & 5 & & Rubus ulmifolius & 10 \\
\hline & & & Corylus avellana & 6 \\
\hline Noble Broadleaves & & & Cotinus coggygria & 6 \\
\hline Acer pseudoplatanus & 5 & 3 & Lonicera xylosteum & 6 \\
\hline Fraxinus excelsior & 4 & 2 & Lonicera etrusca & 5 \\
\hline Tilia sp. & & $<1$ & Rosa sp. & 4 \\
\hline Tilia platyphyllos & 2 & & Berberis vulgaris & 2 \\
\hline Tilia cordata & 1 & & Rhamnus cathartica & 2 \\
\hline Prunus avium & 1 & $<1$ & Euonymus verrucosus & 2 \\
\hline \multirow[t]{2}{*}{ Sorbus torminalis } & 2 & $<1$ & Rosa canina & 2 \\
\hline & & & Cornus sanguinea & 2 \\
\hline Other tree species & & & Euonymus europaeus & 2 \\
\hline Robinia pseudoacacia & 3 & $<1$ & Rubus sp. & 2 \\
\hline Sorbus aria & 2 & 1 & Viburnum lantana & 2 \\
\hline Abies alba & 2 & $<1$ & Rubus fruticosus aggr. & 1 \\
\hline Acer campestre & 2 & $<1$ & Frangula alnus & 1 \\
\hline Castanea sativa & $<1$ & $<1$ & Rosa arvensis & $<1$ \\
\hline Juglans regia & $<1$ & $<1$ & Rosa gallica & $<1$ \\
\hline Malus sylvestris & $<1$ & $<1$ & Rubus bungeana & $<1$ \\
\hline Pyrus pyraster & $<1$ & $<1$ & Rhamnus saxatilis & $<1$ \\
\hline Sorbus aucuparia & $<1$ & $<1$ & Rosa guleana & $<1$ \\
\hline Acer monspessulanum & $<1$ & $<1$ & Rubus caesius & $<1$ \\
\hline Celtis australis & $<1$ & $<1$ & Rubus idaeus & $<1$ \\
\hline Pinus nigra & $<1$ & $<1$ & & \\
\hline
\end{tabular}




\section{References}

1. Bastin, J.F.; Finegold, Y.; Garcia, C.; Mollicone, D.; Rezende, M.; Routh, D.; Zohner, C.M.; Crowther, T.W. The global tree restoration potential. Science 2019, 365, 76. [CrossRef] [PubMed]

2. Löf, M.; Madsen, P.; Metslaid, M.; Witzell, J.; Jacobs, D.F. Restoring forests: Regeneration and ecosystem function for the future. New For. 2019, 50, 139-151. [CrossRef]

3. Krajnc, A. History of deforestation and reforestation in the Dinaric Karst. Geogr. Res. 2009, 47, 15-23.

4. Šercelj, A. The Origins and Development of Forests in Slovenia; Slovene Academy of Arts and Sciences: Ljubljana, Slovenia, 1996. (In Slovenian)

5. Portoghesi, L.; Consalvo, M.; Angelini, A.; Ferrari, B.; Barbati, A.; Castaldi, C.; Corona, P. Multifunctional management of mountain reforestations: Thoughts and perspectives from a case study in central Italy. Ital. J. For. Mt. Environ. 2013, 68, 305-315. [CrossRef]

6. Sánchez-Salguero, R.; Camarero, J.J.; Dobbertin, M.; Fernández-Cancio, Á.; Vilà-Cabrera, A.; Manzanedo, R.D.; Zavala, M.A.; Navarro-Cerrillo, R.M. Contrasting vulnerability and resilience to drought-induced decline of densely planted vs. Natural rear-edge Pinus nigra forests. For. Ecol. Manag. 2013, 310, 956-967. [CrossRef]

7. Gajsek, D.; Jarni, K.; Brus, R. Conversion of old black pine stands using broadleaf tree species in the Slovenian karst. Dendrobiology 2015, 74, 77-84. [CrossRef]

8. Nocentini, S. La rinaturalizzazione dei rimboschimenti. Una prova su pino nero e laricio nel complesso di Monte Morello (Firenze). L'Italia Forestale e Montana 1995, 50, 425-435.

9. Mercurio, R.; Spinelli, R. Exploring the silvicultural and economic viability of gap cutting in Mediterranean softwood plantations. For. Stud. China 2012, 14, 63-69. [CrossRef]

10. Zerbe, S. Restoration of natural broad-leaved woodland in central Europe on sites with coniferous forest plantations. For. Ecol. Manag. 2002, 167, 27-42. [CrossRef]

11. Zlatanov, T.; Velichkov, I.; Lexer, M.J.; Dubravac, T. Regeneration dynamics in aging black pine (Pinus nigra Arn.) plantations on the south slopes of the middle Balkan range in Bulgaria. New For. 2010, 40, 289-303. [CrossRef]

12. Anić, I. Promjena sastojinskog oblika prirodnim pomlađivanjem na primjeru šumske kulture crnoga bora (Pinus nigra Arn.) u Senjskoj Dragi. Šumarski List 2003, 77, 41-49.

13. Mosandl, R.; Kleinert, A. Development of oaks (Quercus petraea (Matt.) Liebl.) emerged from bird-dispersed seeds under old-growth pine (Pinus silvestris L.) stands. For. Ecol. Manag. 1998, 106, 35-44. [CrossRef]

14. Dobrowolska, D. Oak natural regeneration and conversion processes in mixed Scots pine stands. Forestry 2006, 79, 503-513. [CrossRef]

15. Vallauri, D.R.; Aronson, J.; Barbero, M. An analysis of forest restoration 120 years after reforestation on badlands in the southwestern Alps. Restor. Ecol. 2002, 10, 16-26. [CrossRef]

16. Gams, I. Origin of the term "karst" and the transformation of the Classical Karst (kras). Environ. Geol. 1993, 21, 110-114. [CrossRef]

17. ARSO. Eionet (Environmental Information and Observation Network); ARSO Environmental Agency of the Republic of Slovenia: Ljubljana, Slovenia, 2019. Available online: http://eionet-en.Arso.Gov.Si/ (accessed on 22 November 2019).

18. Parent, S.; Messier, C. A simple and efficient method to estimate microsite light availability under a forest canopy. Can. J. For. Res. 1996, 26, 151-154. [CrossRef]

19. IMKO. Trime-ez/-ezc/-It/-Itc User Manual. Available online: http://95.110.175.13/rid=1Q22RVC3H-QC1NPPBKZ/Imko_Humedad_suelo.pdf (accessed on 22 November 2019).

20. ARSO. Pregled Hidroloških Razmer Površinskih Voda v Sloveniji; Poročilo o Monitoringu za leto 2012; Ministrstvo za Okolje in Prostor, Agencija RS za Okolje: Ljubljana, Slovenia, 2012.

21. R Core Team. A Language and Environment for Statistical Computing; R Foundation for Statistical Computing: Vienna, Austria, 2019; Available online: https://www.R-project.org/ (accessed on 24 November 2019).

22. Bolker, B.; Skaug, H.; Magnusson, A.; Nielsen, A. Getting Started with the GlmmADMB Package. 2012. Available online: http://glmmadmb.r-forge.r-project.org/glmmADMB.pdf (accessed on 18 March 2015).

23. Zuur, A.F.; Ieno, E.N.; Walker, N.J.; Saveliev, A.A.; Smith, G.M. Mixed Effects Models and Extensions in Ecology with r; Springer: New York, NY, USA, 2009; p. 574.

24. Robinson, A.P.; Hamann, J.D. Forest Analytics with R: An Introduction; Springer: New York, NY, USA, 2011 ; p. 354. 
25. Landolt, E.; Bäumler, B.; Erhardt, A.; Hegg, O.; Klötzli, F.; Lämmler, W.; Nobis, M.; Rudmann-Maurer, K.; Schweingruber, F.; Theurillat, J. Flora Indicativa: Ökologische Zeigerwerte und Biologische Kennzeichen zur Flora der Schweiz und der Alpen; Haupt: Bern, Switzerland, 2010; p. 378.

26. Lepš, J.; Šmilauer, P. Multivariate Analysis of Ecological Data Using CANOCO; Cambridge University Press: Cambridge, UK, 2003; p. 362.

27. Oksanen, J.; Guillaume, B.; Friendly, M.; Kindt, R.; Legendre, P.; McGlinn, D.; Minchin, P.R.; O'Hara, R.B.; Simpson, G.L.; Solymos, P.; et al. Community Ecology Package. Available online: https//CRAN.R-project. org/package=vegan (accessed on 22 November 2019).

28. Legendre, P.; Anderson, M.J. Distance-based redundancy analysis: Testing multispecies responses in multifactorial ecological experiments. Ecol. Monogr. 1999, 69, 1-24. [CrossRef]

29. Cáceres, M.D.; Legendre, P. Associations between species and groups of sites: Indices and statistical inference. Ecology 2009, 90, 3566-3574. [CrossRef]

30. Nussbaumer, A.; Waldner, P.; Etzold, S.; Gessler, A.; Benham, S.; Thomsen, I.M.; Jørgensen, B.B.; Timmermann, V.; Verstraeten, A.; Sioen, G. Patterns of mast fruiting of common beech, sessile and common oak, Norway spruce and Scots pine in Central and Northern Europe. For. Ecol. Manag. 2016, 363, 237-251. [CrossRef]

31. Caldeira, M.C.; Ibáñez, I.; Nogueira, C.; Bugalho, M.N.; Lecomte, X.; Moreira, A.; Pereira, J.S. Direct and indirect effects of tree canopy facilitation in the recruitment of Mediterranean oaks. J. Appl. Ecol. 2014, 51, 349-358. [CrossRef]

32. Pulido, F.J.; Díaz, M. Regeneration of a Mediterranean oak: A whole-cycle approach. Ecoscience 2005, 12, 92-102. [CrossRef]

33. Oberlechner, V.; Vacik, H. Regeneration and growth success of downy oak (Quercus pubescens) in secondary Austrian black pine forests (Pinus nigra) in Vinschgau, Southtyrol. Allgemeine Forst und Jagdzeitung 2003, 174, 219-226.

34. Gray, A.N.; Spies, T.A.; Easter, M.J. Microclimatic and soil moisture responses to gap formation in coastal Douglas-fir forests. Can. J. For. Res. 2002, 32, 332-343. [CrossRef]

35. Vilhar, U.; Roženbergar, D.; Simončič, P.; Diaci, J. Variation in irradiance, soil features and regeneration patterns in experimental forest canopy gaps. Ann. For. Sci. 2015, 72, 253-266. [CrossRef]

36. Prevosto, B.; Monnier, Y.; Ripert, C.; Fernandez, C. Can we use shelterwoods in Mediterranean pine forests to promote oak seedling development? For. Ecol. Manag. 2011, 262, 1426-1433. [CrossRef]

37. Eiberle, K.; Nigg, H. Grundlagen zur Beurteilung des Wildverbisses im Gebirgswald. Schweiz. Z. Forstwes. 1987, 138, 747-780.

38. Hester, A.; Bergman, M.; Iason, G.; Moen, J. Impacts of large herbivores on plant community structure and dynamics. In Large Herbivore Ecology, Ecosystem Dynamics and Conservation; Danell, K., Bergstrom, R., Duncan, P., Pastor, J., Eds.; Cambridge University Press: Cambridge, UK, 2006; pp. 97-141.

39. Barbalat, S.; Junod, P.; Plachta, M. Silviculture of two heliophilic tree species and insect fauna diversity. Schweiz. Z. Forstwes. 1997, 148, 789-807.

40. Mercurio, R.; Mallamaci, C.; Muscolo, A.; Sidari, M. Gap size effects on tree regeneration in afforestations of black pine (Pinus nigra arn.). Forest 2009, 6, 312-319. [CrossRef]

41. Schütz, J.-P.; Saniga, M.; Diaci, J.; Vrska, T. Comparing close-to-nature silviculture with processes in pristine forests: Lessons from central europe. Ann. For. Sci. 2016, 73, 911-921. [CrossRef]

(C) 2019 by the authors. Licensee MDPI, Basel, Switzerland. This article is an open access article distributed under the terms and conditions of the Creative Commons Attribution (CC BY) license (http://creativecommons.org/licenses/by/4.0/). 